\title{
December 23 Highlight and Commentary
}

\section{Gabapentin in chronic daily headache prophylaxis}

In a placebo-controlled study by Spira et al., gabapentin was significantly superior to placebo for the primary efficacy variable for chronic daily headache prophylaxis: 9.1\% difference in headache-free rates. Other measures were also significantly better with gabapentin, including headache-free days/months, severity, and quality of life.

see page 1753

\section{Gabapentin in the treatment of chronic daily headache}

\author{
Commentary by Stephen D. Silberstein, MD, FACP
}

Chronic daily headache (CDH) refers to headache disorders that occur 15 or more days a month. It is not a diagnosis, but a group of disorders that includes chronic tension-type headache, chronic migraine (CM), new daily persistent headache, and hemicrania continua. All are now included in the new International Headache Society (IHS) classification. ${ }^{1,2}$

CM was previously called transformed migraine or mixed headache. Patients who have CM often have a history of migraine without aura, and features of migraine, including trigger factors, unilaterality, and nausea, often persist. Superimposed full-blown migraine attacks can occur. The IHS now classifies CM as a complication of migraine (table). When acute medication overuse is present, medication-overuse headache $(\mathrm{MOH})$ is diagnosed. ${ }^{1}$ Overuse is defined in treatment days/month. The criteria for ergotamine, triptan, opioid, and combination medication overuse require intake on $\geq 10$ days/ month. Simple analgesic overuse requires the intake of simple analgesics on $\geq 15$ days/month. ${ }^{1}$

Patients WITH CDH are difficult to treat. The following steps approach is sensible: exclude secondary headache disorders; diagnose the specific primary headache disorder; identify comorbid medical and psychiatric conditions, as well as exacerbat-

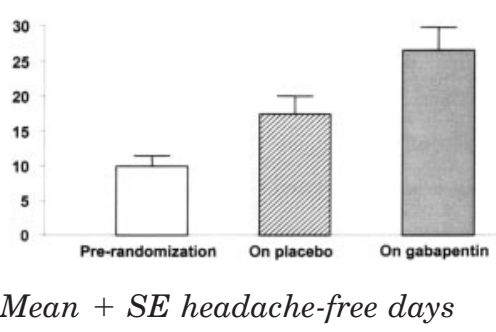

ing factors, especially medication overuse; limit all symptomatic medications (with the possible exception of the long-acting nonsteroidal antiinflammatory drugs); and start the patient on a program of preventive medication with the explicit understanding that the drugs may not become fully effective until medication overuse has been eliminated and detoxification (the washout period) completed.

Most preventive agents used for primary $\mathrm{CDH}$ have not been examined in well-designed doubleblind studies. Thus the study of Spira et al. is a welcome addition to the field. However, there are limitations to their study.

First, Spira et al. defined CDH as headache that occurs at least 15 days a month and lasts at least 4 hours a day for at least 6 months, but they did not subclassify it. What were they treating with gabapentin? The study preceded the new IHS criteria, but did not use the Silberstein-Lipton criteria for the diagnosis of $\mathrm{CDH}$ subtypes. Thus they did not meet the first cardinal rule: diagnose the specific primary headache disorder. Most patients had mixed headache (probably $\mathrm{CM}$ ) and were overusing analgesics $(\mathrm{MOH})$. Second, this study did not take into account analgesic overuse, which is a major confounding factor in both the treatment and interpretation of treatment results. Patients were not excluded if they were overusing analgesics, but were excluded if they overused ergots and triptans. This can confound the results. ${ }^{3}$ The 25 subjects who met their criteria for overuse did, in fact, do worse. Third, although their results were significant, they were modest $(9.1 \%$ difference in headache-free days) and may not be clinically important. Future CDH studies require subset analysis and control for acute medication overuse.

\section{References}

1. Headache Classification Committee. The international classification of headache disorders, 2nd ed. Cephalalgia 2004;24(suppl 1):1-160.

2. Silberstein SD, Lipton RB, Sliwinski M. Classification of daily and near-daily headaches: field trial of revised IHS criteria. Neurology 1996;47:871-75.

3. Limmroth V, Katsarava Z, Fritsche G, Przywara S, Diener HC. Features of medication overuse headache following overuse of different acute headache drugs. Neurology 2002;59:1011-1014.

see page 1753 


\title{
Neurology
}

\author{
December 23 Highlight and Commentary \\ Neurology 2003;61;1637 \\ DOI 10.1212/WNL.61.12.1637
}

This information is current as of December 22, 2003

\section{Updated Information \&} Services

References

Citations

Permissions \& Licensing

Reprints including high resolution figures, can be found at: http://n.neurology.org/content/61/12/1637.full

This article cites 2 articles, 2 of which you can access for free at: http://n.neurology.org/content/61/12/1637.full\#ref-list-1

This article has been cited by 2 HighWire-hosted articles: http://n.neurology.org/content/61/12/1637.full\#\#otherarticles

Information about reproducing this article in parts (figures,tables) or in its entirety can be found online at:

http://www.neurology.org/about/about_the_journal\#permissions

Information about ordering reprints can be found online:

http://n.neurology.org/subscribers/advertise

Neurology ${ }^{\circledR}$ is the official journal of the American Academy of Neurology. Published continuously since 1951, it is now a weekly with 48 issues per year. Copyright . All rights reserved. Print ISSN: 0028-3878. Online ISSN: 1526-632X.

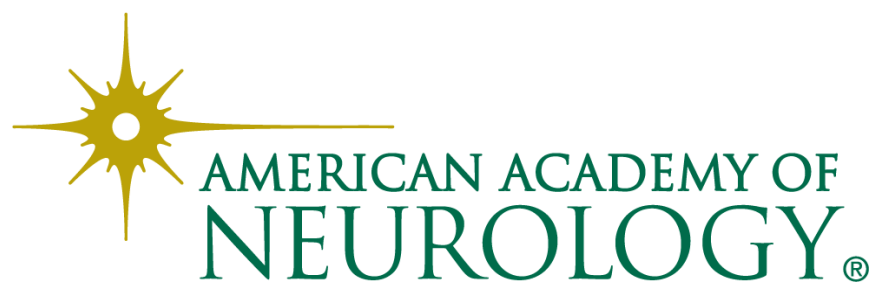

